Egyptian Journal of Aquatic Biology \& Fisheries

Zoology Department, Faculty of Science,

Ain Shams University, Cairo, Egypt.

ISSN $1110-6131$

Vol. 23(2): 475 - 490 (2019)

www.ejabf.journals.ekb.eg

\title{
Environmental Characteristics of the Egyptian Mediterranean Coast
}

\author{
Naglaa A. El-Naggar*, Laila A. Mohamed, Ahmed Abdel-Halim and \\ Hosny E. Emara \\ Marine Chemistry Department, Environmental Division, National Institute of Oceanography \\ and Fisheries, Alexandria, Egypt. \\ Corresponding Author: *Naglaa.elnaggar@gmail.com
}

\section{ARTICLE INFO}

Article History:

Received: April 7, 2019

Accepted: May 30, 2019

Online: June8, 2019

Keywords:

Mediterranean Sea

Environment

Amino acids

PHs

Pesticides

PCBs

Egypt

\section{ABSTRACT}

In an attempt to evaluate the environmental quality of the Egyptian Mediterranean Sea from El-Dabaa to El-Saloum, environmental parameters as well as amino acids, petroleum hydrocarbons, pesticides and PCBs have been studied in water and sediment samples from seven different locations during the year 2014. Spatial and temporal fluctuations as well as statistical analysis between the analyzed variables were examined.

The results demonstrated a wide range of water temperature (13.50$29.00^{\circ} \mathrm{C}$ ), slightly narrow fluctuations in salinity (37.20-38.78), and welloxygenated seawaters $(6.40-8.96 \mathrm{mg} \mathrm{O} / \mathrm{l})$, relatively low amounts of oxidizable organic matter $\left(0.10-1.60 \mathrm{mg} \mathrm{O}_{2} / \mathrm{l}\right)$ and the seawater was slightly alkaline ( $\mathrm{pH}$ range 8.04-8.63). Nutrient characteristics sustained the levels up to $2.45,5.42,5.40,0.28$ and $5.36 \mu \mathrm{M}$ for reactive phosphates, reactive silicates, ammonium, nitrite and nitrate, respectively.

These obtained results signified that water quality from El-Dabaa to El-Saloum is good; within the permissible limits in the majority of monitoring sites, and all stations were generally between Oligotrophic and mesotrophic states, characterized by a relatively low to medium level of nutrients.

Furthermore, seawater from the most sites did not show any levels of pesticides, PCBs and petroleum hydrocarbons. These levels, if any, may have been much lower than the detection limit for the compounds analyzed. In marine sediments, the concentrations of amino acids demonstrated a range of 1884.5-19569.6 $\mu \mathrm{M}$, while pesticides, PCBs, and petroleum hydrocarbons were below detection limit to 3086, 120, 145 $\mathrm{ng} / \mathrm{g}$; respectively. These results are much lower in sediment of the western part of the Egyptian Mediterranean coast compared to other sites and also much lower than permissible levels given by National Academy of Sciences and National Academy of Engineering.

\section{INTRODUCTION}

Egypt is in the northern corner of Africa with the entire northern part bordering the Mediterranean Sea. The Egyptian coastline Mediterranean Sea extends over $1,550 \mathrm{~km}^{2}$ from Rafah in the east to El-Saloum in the west and is one of the longest shores in North Africa. 40\% of Egypt's industries are located in the Mediterranean coast, this region is extremely important economically, with substantial capital investment. 
However, The Egyptian marine environment along the Mediterranean Coast has been subjected to a substantial increase since the last decades of pollution due to a great number of industrial, agricultural, commercial and domestic waste effluents and emissions as well as hazardous substances (Emara et al, 1992; El-Deeb 2007; Fathy et al, 2012; Shreadah et al. 2014). Marine pollution affects water, sediments and biota. It can be related to oxygen-depleting substances, persistent organic pollutants (POPs), petroleum hydrocarbons, nutrients introduced by human activities or debris. Many different kinds of pollutants enter the Mediterranean Sea from its shores (land-based sources) either by discharge points and dumping grounds (pointsource pollution) or from surface fluvial run-off (non-point-source pollution). Pollutants also enter the marine environments by atmospheric deposition, while others are introduced directly by marine activities such as shipping, fishing, mining, and oil and gas exploration.

Water quality is a critical factor significantly affects human and all oceanic organism health. Monitoring of the environmental quality is of great importance to determine effectiveness order of all the adopted governmental steps and if further steps are required to improve the quality of the environment. Water quality parameters that are commonly monitored include temperature, dissolved oxygen (DO), oxidizable organic matter $(\mathrm{OOM}), \mathrm{pH}$, salinity and nutrients. Little attention was paid to investigate physicochemical characteristics of coastal waters of the western region of Mediterranean Sea.

Although dissolved free amino acids (DFAA) are present in trace amounts in natural water, there was great interest in studying DFAA in coastal and oceanic waters because these compounds are a good nitrogen source for marine microalgae and bacteria (Tada et al., 1998). Amino acids are the building blocks of protein molecules, making up the largest reservoir of organic nitrogen in most organisms. These compounds account about half of particulate organic nitrogen and one quarter of particulate organic carbon in surface waters. Amino acids are the most studied biochemical classes in organic geochemistry, because they are major constituents of phytoplankton (Wakeham et al., 1997). The studies of distribution of amino acid in water and sediments of the Egyptian Mediterranean Sea from El-Dabaa to El-Saloum is poor; with little known in different regions of the Mediterranean Sea; for example Emara (1983) reported values from 0.81 to $9.37 \mathrm{mg} / \mathrm{l}$ for unpolluted and polluted seawater areas, respectively at Alexandria coastal water.

Generally petroleum hydrocarbons have a wide range of industrial, anthropogenic applications. They are of great concern and globally distributed through the environment due to their persistence, high bioaccumulation potential and harmful biological effects (Iwata et al. 1993). Once discharged into the marine systems, these chemicals disperse into three phases, water and sediment and biota. Hence, it is important to study the distribution of these compounds in these compartments. The composition of hydrocarbon can be changed due to evaporation, chemical reactions, selective dissolution, biodegradation and photo-oxidation. Simple aromatics and short chain alkanes are rapidly lost, but higher molecules such as hopanes and steranes are little affected and can be particularly useful markers in investigations (Volkman et al., 1992).

Persistent organic pollutants (POPs), including organochlorine pesticides (OCPs) and polychlorinated biphenyls (PCBs) are used to refer to the organic compounds that are found in the environment in very small amounts and can cause significant harm to ecological systems and/or humans. OCPs and PCBs compounds were found widespread in the environmental media, such as in water, air, sediment 
and biota; and globally distributed including remote areas where they have never been used (Koziol and Pudykiewicz, 2001). The OCPs could spread into aquatic environments through runoffs from non-point soil sources and have been a major environmental issue, drawing extensive attention to environmental scientists and the public (Jiang et al., 2009; Emara et al. 2010; El Naggar et al., 2013).

PCBs are a class of 209 congeners, each of which consists of two benzene rings and one to ten chlorine atoms (Hutzinger et al., 1974). The PCBs are thermally stable, highly lipophilic, and have low flammability (De Voogt and Brinkman, 1989). The PCBs have been shown to bio-accumulate within food chains and they have been detected in different environmental compartments worldwide (Lundgren et al., 2002). It is well known that over one hundred PCBs were identified in the technical PCBs mixtures. However, only a part of them could be detected at significant levels in nature. Moreover, it is highly cost-effective to monitor fewer congeners, especially since it may be possible to acquire nearly all desired information from a reduced set of measurements, due to the high correlation of many PCB congeners. The usage of PCBs in Egypt is not well established, but the use of PCBs in electrical equipment, transformers, and other industries is common, owing to their persistence, PCB contaminations are widespread at the Alexandria Harbor (Barakat et al., 2002).

Studying of the environmental quality of the environment and focusing on pollutants known to be most harmful to human health (for example OCPs, PCBs, petroleum hydrocarbons) introduced by human activities or debris are of great importance to determine the order of effectiveness of all the adopted governmental steps and to determine if further different steps are required to improve the quality of the environment. Thus, the objectives of the present study were set to study the water quality of the Egyptian Mediterranean Coast from El-Saloum to El-Dabaa by measuring of physical and chemical characteristics of the study area; water temperature, $\mathrm{pH}$, salinity, $\mathrm{DO}$, ammonia, nitrite, nitrate, reactive phosphate and reactive silicate, in addition; investigating the distribution of amino acids, petroleum hydrocarbons, PCBs and OCPs in surface water and sediments to evaluate its environmental quality and put a monitoring and management plan for development this important ecosystem to help support the decision-making processes related to the management of marine and coastal ecosystems.

\section{MATERIALS AND METHODS}

\section{Sampling}

Samples were collected from seven stations (El-Dabaa E, El-Dabaa W, Alam Elrom, Mrsa Matrouh, El-Negala, Sidi Braani, and El-Saloum) from the Egyptian Mediterranean Coast from El-Saloum in the East to El-Dabaa in the West through four seasonal cruises during the year 2014. The sampling area and location of stations are shown in Fig. (1) and Table (1).

Coastal water samples were collected using Niskin bottles at $2 \mathrm{~m}$ depth, while surface sediment samples were collected during winter and summer seasons only using a stainless steel grab sampler. Samples were preserved and moved to the laboratory, where stored at $-20^{\circ} \mathrm{C}$. 
Table 1: Sampling locations of the Egyptian Mediterranean Coast from El-Dabaa to El-Saloum

\begin{tabular}{cccc}
\hline Station & Locations & Longitude (E) & Latitude (N) \\
\hline 1 & El-Dabaa E & 28.83016011 & 30.9245369 \\
2 & El-Dabaa W & 28.57504837 & 31.02168065 \\
3 & Alam Elrom & 27.51303089 & 31.19583927 \\
4 & Mrsa Matrouh & 27.30736619 & 31.31836292 \\
5 & El-Negala & 26.70262446 & 31.46451613 \\
6 & Sidi Braani & 25.90272007 & 31.62467204 \\
7 & El-Saloum & 25.13694727 & 31.54153099 \\
\hline
\end{tabular}

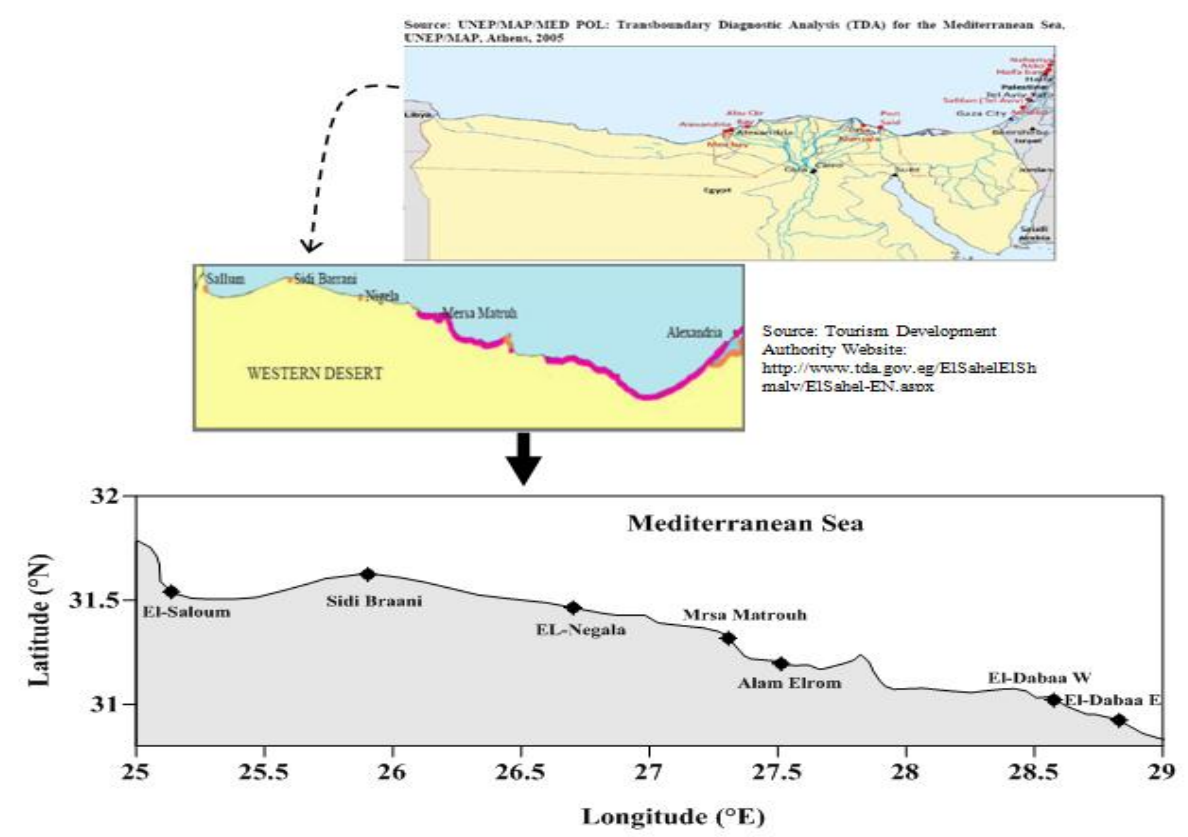

Fig. 1: Sampling stations along the Egyptian western Mediterranean Coast from El-Dabaa to ElSaloum.

\section{Physico-chemical parameters and nutrients}

The following physico-chemical variables: temperature, $\mathrm{pH}$ and salinity were measured directly in situ using CTD apparatus (Model: YSI 556). Dissolved oxygen (DO) was determined by the modified Winkler method (Grasshoff 1976), oxidizable organic matter (OOM) according to FAO method (FAO 1976). Nutrients (ammonia, nitrite, nitrate, phosphate, and silicate) were analyzed spectrophotometrically by the recent oceanographically methods described by Grasshoff using UV/Visible double beam spectrophotometer (janway Model: 6800). Total phosphorus (TP) and total nitrogen (TN) were determined simultaneously spectrophotometrically according to Valderama (1981). Various statistical analysis of the results occurred using SPSS programme (version 22).

\section{Amino acids Analysis}

Hydro1yzable amino acids (AA) were analyzed in sediment during summer season only with Amino Acid Analyzer; a Pharmacia LKB (Freiburg, Germany) Alpha Plus 4151, after hydrolysis with $6 \mathrm{~N} \mathrm{HCl}$ for $22 \mathrm{~h}$ at $110{ }^{\circ} \mathrm{C}$. An aliquot hydrolysate was evaporated to dryness, and taken up in distilled water and evaporated to dryness twice again to remove the remaining HCI. The residue in an acidic buffer solution was taken up and injected into the Amino Acid Analyzer. Duplicate analyses resulted in an average variability of $8.2 \%$ for AA. Average variability of the major individual amino acids lies in the range of 5-15\%. AA concentrations were multiplied by a factor of 1.4 to compensate for losses during hydrolysis (Muller et al., 1986). 


\section{Petroleum Hydrocarbons Analysis}

Petroleum hydrocarbons in seawater and sediment were sampled during summer and winter 2014. Seawater were extracted on board, stored at $-4^{\circ} \mathrm{C}$, and transported to the laboratory for aliphatic and aromatic hydrocarbons analysis using well-established techniques (UNEP/IOC/IAEA 1992). Seawater samples were extracted in a separating funnel with $60 \mathrm{ml}$ of dichloromethane three times. Sample extracts were combined and concentrated by rotary evaporation to $5 \mathrm{ml}$. Finally, samples were concentrated to a final volume of $1 \mathrm{ml}$ under a gentle stream of pure nitrogen. $30 \mathrm{~g}$ of the sediment samples was mixed with $90 \mathrm{~g}$ of anhydrous sodium sulfate. From each sediment sample, duplicate samples were taken. Extraction of sediment samples was taken in a Soxhlet extractor with $250 \mathrm{ml}$ of hexane for $8 \mathrm{~h}$ and then re-extracted for $8 \mathrm{~h}$ into $250 \mathrm{ml}$ of dichloromethane. The extracts were then combined and desulfurized through activated copper powder and then concentrated in a rotary evaporator at low temperature $\left(35^{\circ} \mathrm{C}\right)$, followed by a nitrogen gas stream to about $1 \mathrm{ml}$. Fractionation and clean-up were performed by passing the extract (water and sediment samples) through a silica/alumina column. Silica column was prepared by slurry packing $10 \mathrm{~g}$ of silica, followed by $10 \mathrm{~g}$ of alumina and finally $1 \mathrm{~g}$ of anhydrous sodium sulfate. Elution was performed using 40ml of hexane (F1: aliphatic fractions), then $40 \mathrm{ml}$ of hexane/dichloromethane 90/10 (F2: aromatic fractions), followed by $20 \mathrm{ml}$ of dichloromethane/hexane 50/50 (F3: polyaromatic fractions), both of F2 and F3 fractions were combined to give PAHs. Finally, eluted samples were concentrated to about $1 \mathrm{ml}$ under a gentle stream of purified nitrogen. Finally analysis of samples was carried out by GC gas chromatograph equipped with a flame ionization detector (FID).

\section{OCPs and PCBs Analysis}

OCPs and PCBs in seawater and sediment were sampled during summer and winter 2014. Around 1 liter of the water sample was extracted three times with 100 $\mathrm{ml}$ of dichloromethane. The combined extracts were filtered and concentrated in a vacuum rotary evaporator (UNEP/IOC/IAEA 1991). 30g of the sediment samples was treated with $10 \mathrm{~g}$ of sodium sulfate and extracted with $250 \mathrm{ml}$ of hexane for $8 \mathrm{~h}$ in a Soxhlet extractor and then re-extracted for $8 \mathrm{~h}$ into $250 \mathrm{ml}$ of dichloromethane. Dichloromethane $(100 \mathrm{ml})$ was extracted in the same fashion as the sample and used as the blank. The extracted and blanks samples were then concentrated to a volume of $2 \mathrm{ml}$ with a pure nitrogen gas stream. Fractionation and clean-up were carried out by passing the extract (water and sediment) through a silica/alumina column. Silica column was prepared by slurry packing $10 \mathrm{~g}$ of silica, followed by $10 \mathrm{~g}$ of alumina and finally $1 \mathrm{~g}$ of anhydrous sodium sulfate. Elution was performed using $70 \mathrm{ml}$ of hexane for PCBs congeners (F1), followed by elution with a $50 \mathrm{ml}$ mixture containing $70 \%$ hexane and $30 \%$ dichloromethane for pesticide fraction (F2). Finally, eluted samples were concentrated to about $0.2 \mathrm{ml}$ using a gentle stream of purified nitrogen, prior to injection into GC/FID for analysis.

\section{RESULTS AND DISCUSSION}

\section{Physico-chemical parameters and nutrients}

The physico-chemical parameters (water temperature, DO, OOM, salinity and $\mathrm{pH}$ ) during the year 2014 are illustrated in Table (2). Water temperature varied seasonally from a minimum of $13.5^{\circ} \mathrm{C}$ during winter at Sidi Braani to a maximum of 29.0 and $26{ }^{\circ} \mathrm{C}$ during spring and summer at Mrsa Matrouh and El-Saloum, respectively (Fig. 2a). Salinity, as temperature, is very important limiting factor, 
which affects the biological distribution of the marine environment. Salinity in the present study showed a slightly narrow seasonal variation (Fig. 2b). The lowest salinity value of 37.2 was recorded during spring at El-Dabaa E, while summer represented the highest salinity value of 38.78 recorded at El-Dabaa W. Regionally, the average values of salinity, in general, showed a narrow local variation ranged between 37.62 and 38.37; whereas, the annual salinity average was 38.04.

Hydrogen ion concentration plays an important role in many of the life processes in sea; living organisms are very dependent on and sensitive to it. It is dependent on the interaction of numerous substances dissolved in water, photosynthetic activity of aquatic plants, respiration of aquatic organisms, decomposition of organic matter, precipitation and/or dissolution of $\mathrm{CO}_{2}$ components and oxidation-reduction reactions (Riley et al. 1978). Seawater samples lie in the alkaline side (>7 to $<9$ ). The maximum reading of $\mathrm{pH}$ value $(8.63)$ was observed during winter at Mrsa Matrouh, while the lowest value (8.04) was recorded at ElDabaa E and W during spring (Fig. 2c). Negative and positive correlation found between $\mathrm{pH}$ and both temperature, salinity, respectively $(\mathrm{r}=-0.44,0.44, \mathrm{n}=28, \mathrm{p}$ $<0.05)$.

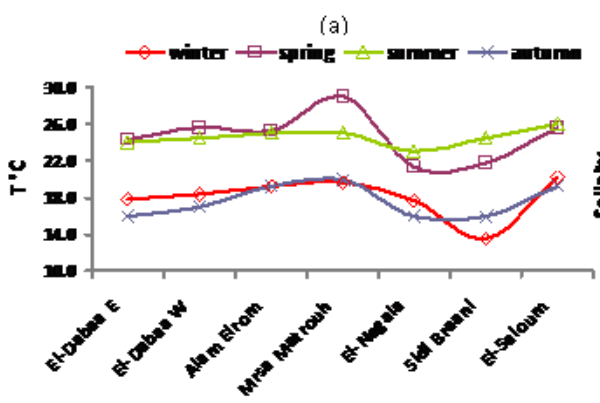

(c)

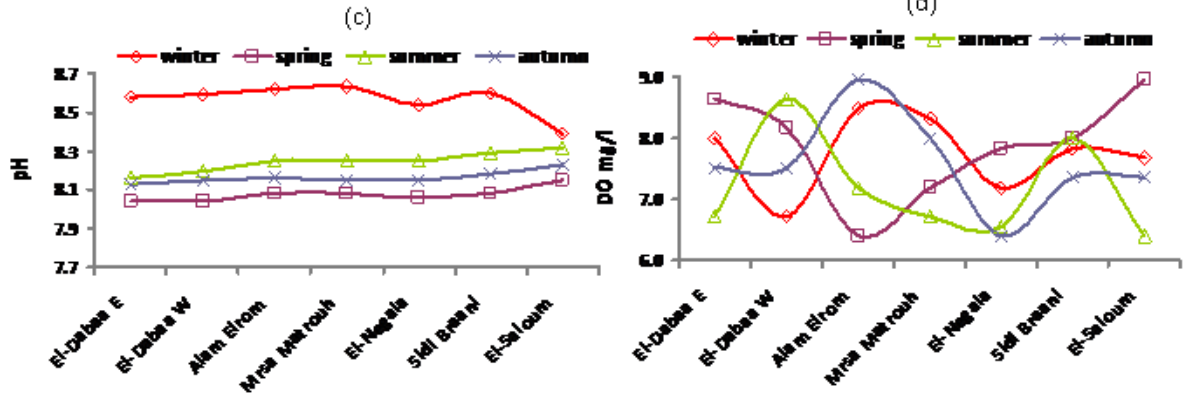

(e)

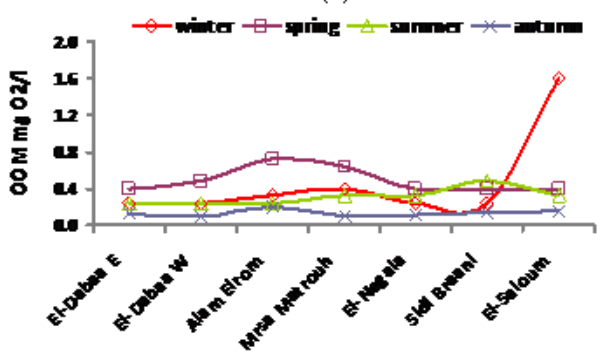

(b)

(d)

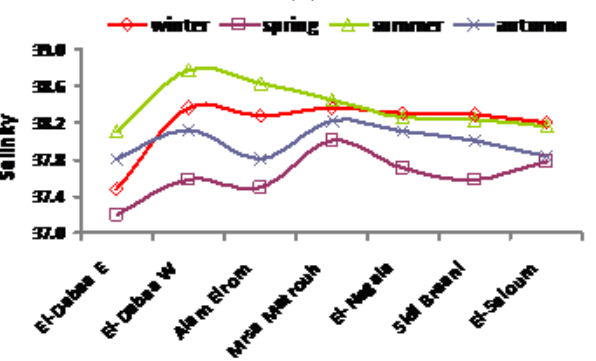

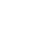<smiles>C1CCC1</smiles> 
Table 2: Seasonal values of physical and chemical parameters of water from El-Dabaa to El-Saloum along the Egyptian Mediterranean Sea during the year 2014.

\begin{tabular}{|c|c|c|c|c|c|c|}
\hline Station & & $\mathbf{T}^{\circ} \mathbf{C}$ & Salinity & pH & DO & OOM \\
\hline El-Dabaa E & \multirow{7}{*}{ 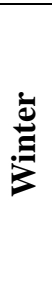 } & 17.80 & 37.48 & 8.58 & 8.00 & 0.24 \\
\hline El-Dabaa W & & 18.40 & 38.36 & 8.59 & 6.72 & 0.24 \\
\hline Alam Elrom & & 19.20 & 38.28 & 8.62 & 8.48 & 0.32 \\
\hline Mrsa Matrouh & & 19.60 & 38.36 & 8.63 & 8.32 & 0.40 \\
\hline El-Negala & & 17.60 & 38.30 & 8.54 & 7.20 & 0.24 \\
\hline Sidi Braani & & 13.50 & 38.29 & 8.60 & 7.84 & 0.24 \\
\hline El-Saloum & & 20.20 & 38.20 & 8.39 & 7.68 & 1.60 \\
\hline El-Dabaa E & \multirow{7}{*}{ 象 } & 24.30 & 37.20 & 8.04 & 8.64 & 0.40 \\
\hline El-Dabaa W & & 25.65 & 37.58 & 8.04 & 8.16 & 0.48 \\
\hline Alam Elrom & & 25.25 & 37.50 & 8.08 & 6.40 & 0.72 \\
\hline Mrsa Matrouh & & 29.00 & 38.01 & 8.08 & 7.20 & 0.64 \\
\hline El-Negala & & 21.40 & 37.71 & 8.06 & 7.84 & 0.40 \\
\hline Sidi Braani & & 21.80 & 37.58 & 8.08 & 8.00 & 0.40 \\
\hline El-Saloum & & 25.65 & 37.78 & 8.15 & 8.96 & 0.40 \\
\hline El-Dabaa E & \multirow{7}{*}{ 总 } & 24.00 & 38.11 & 8.16 & 6.72 & 0.24 \\
\hline El-Dabaa W & & 24.50 & 38.78 & 8.20 & 8.64 & 0.24 \\
\hline Alam Elrom & & 25.00 & 38.63 & 8.25 & 7.20 & 0.24 \\
\hline Mrsa Matrouh & & 25.00 & 38.44 & 8.25 & 6.72 & 0.32 \\
\hline El-Negala & & 23.00 & 38.26 & 8.25 & 6.56 & 0.32 \\
\hline Sidi Braani & & 24.50 & 38.23 & 8.29 & 8.00 & 0.48 \\
\hline El-Saloum & & 26.00 & 38.17 & 8.32 & 6.40 & 0.32 \\
\hline El-Dabaa E & \multirow{7}{*}{$\underset{\Xi}{\Xi}$} & 16.00 & 37.81 & 8.13 & 7.52 & 0.13 \\
\hline El-Dabaa W & & 17.00 & 38.12 & 8.15 & 7.52 & 0.10 \\
\hline Alam Elrom & & 19.20 & 37.81 & 8.16 & 8.96 & 0.19 \\
\hline Mrsa Matrouh & & 20.00 & 38.22 & 8.15 & 8.00 & 0.10 \\
\hline El-Negala & & 16.00 & 38.11 & 8.15 & 6.40 & 0.11 \\
\hline Sidi Braani & & 16.00 & 38.01 & 8.18 & 7.36 & 0.14 \\
\hline El-Saloum & & 19.20 & 37.84 & 8.23 & 7.36 & 0.16 \\
\hline
\end{tabular}

Dissolved oxygen is vital to aquatic life, as it is needed to keep organisms alive. Coastal waters typically require a minimum of $4.0 \mathrm{mg} / \mathrm{l}$ and do better with 5.0 $\mathrm{mg} / \mathrm{l}$ of oxygen to provide for optimum ecosystem function and highest carrying capacity (UNESCO/WHO, 1978) and used as basic water criteria in assessing the degree of pollution in any aquatic environment. The distribution pattern of DO showed a relatively wide seasonally variation and fluctuated between $6.4 \mathrm{mg} / \mathrm{l} \mathrm{during}$ spring and autumn at Alam Elrom and El-Negala, respectively; and $8.96 \mathrm{mg} / \mathrm{l}$ during spring at El-Saloum with an annual average of $7.60 \mathrm{mg} / \mathrm{l}$ (Fig. 2d). Available data show that the increase in DO concentrations confirms the good quality of water.

Oxidizable organic matter, (OOM) uses as basic water quality parameter and indicates only the amount of carbonaceous organic matter (Carlberg, 1972) to assess organic pollution, adversely affecting aquatic life, principally through oxygen depletion. A relatively narrow range in seasonal values at the present study was illustrated in (Fig. 6e), 0.10-1.60 $\mathrm{mg} \mathrm{O}_{2} / \mathrm{l}$; the lowest value was recorded at stations of El-Dabaa W, Mrsa Matrouh during autumn, while the highest value recorded at El-Saloum station during winter, this is due to sewage from small village. The present annual means at water samples were around 0.13-0.49 $\mathrm{mg} \mathrm{O}_{2} / 1$ (annual average $0.35 \mathrm{mg} \mathrm{O} / \mathrm{l}$ ).

The nutrient salts (ammonium ion, nitrite, nitrate, reactive phosphate and reactive silicate) concentrations during the year 2014 are reported in Table (3). Ammonia is the nitrogenous end product of bacterial decomposition of natural organic matter containing nitrogen (Tadros et al., 2005). Ammonia concentration in water samples reached a maximum value during winter and a minimum value during 
autumn being 5.40 and $0.27 \mu \mathrm{M}$ at stations of Mrsa Matrouh and El-Dabaa E; respectively, with an annual average of $1.39 \mu \mathrm{M}$. Most species of phytoplankton utilize the ammonium ion in preference to other inorganic nitrogen forms, which clearly appeared during autumn. Ammonia concentrations were less than permissible limit $(0.5 \mathrm{mg} / \mathrm{l})$, but it exceeded this limit at one point in Mrsa Matrouh where its concentration was $0.54 \mu \mathrm{M}$. Positive correlation found between ammonia and

salinity $(\mathrm{r}=0.51, \mathrm{n}=28, \mathrm{p}<0.05)$. The distribution of ammonia in the study area is illustrated in Fig. (3a).

Table 3: Seasonal values of nutrients in water samples collected from El-Dabaa to El-Saloum along the Egyptian Mediterranean Sea during the year 2014.

\begin{tabular}{|c|c|c|c|c|c|c|c|}
\hline Station & & $\mathrm{NH}_{4}^{+}$ & $\mathrm{NO}_{2}^{-}$ & $\mathrm{NO}_{3}^{-}$ & DIN & $\mathrm{PO}_{4}{ }^{3-}$ & $\mathrm{SiO}_{4}{ }_{4}^{2-}$ \\
\hline El-Dabaa E & & 0.45 & 0.18 & 2.11 & 2.74 & 0.19 & 2.00 \\
\hline El-Dabaa W & & 4.50 & 0.15 & 2.22 & 6.87 & 0.19 & 3.65 \\
\hline Alam Elrom & $\overline{ \pm}$ & 2.34 & 0.15 & 1.28 & 3.77 & 0.10 & 0.46 \\
\hline Mrsa Matrouh &.$\underline{\Xi}$ & 5.40 & 0.28 & 4.35 & 10.03 & 0.00 & 0.23 \\
\hline El-Negala & 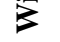 & 1.17 & 0.10 & 0.24 & 1.51 & 0.14 & 1.65 \\
\hline Sidi Braani & & 2.57 & 0.03 & 0.63 & 3.22 & 0.19 & 1.25 \\
\hline El-Saloum & & 1.13 & 0.00 & 0.26 & 1.39 & 0.29 & 0.40 \\
\hline El-Dabaa E & & 1.35 & 0.05 & 0.31 & 1.71 & 0.10 & 0.23 \\
\hline El-Dabaa W & & 0.77 & 0.05 & 0.13 & 0.95 & 0.00 & 0.17 \\
\hline Alam Elrom & 00 & 0.36 & 0.10 & 0.26 & 0.72 & 0.00 & 3.71 \\
\hline Mrsa Matrouh & 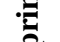 & 1.35 & 0.08 & 0.84 & 2.26 & 0.05 & 0.86 \\
\hline El-Negala & $\frac{2}{n}$ & 0.72 & 0.08 & 0.29 & 1.08 & 0.05 & 0.80 \\
\hline Sidi Braani & & 0.68 & 0.18 & 0.01 & 0.86 & 0.10 & 0.23 \\
\hline El-Saloum & & 1.26 & 0.18 & 0.01 & 1.44 & 0.24 & 1.71 \\
\hline El-Dabaa E & & 1.08 & 0.08 & 3.46 & 4.62 & 0.72 & 5.42 \\
\hline El-Dabaa W & & 2.34 & 0.13 & 3.46 & 5.93 & 2.45 & 5.07 \\
\hline Alam Elrom & 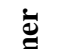 & 2.48 & 0.05 & 4.86 & 7.39 & 1.10 & 3.31 \\
\hline Mrsa Matrouh & 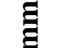 & 1.53 & 0.05 & 5.02 & 6.60 & 0.43 & 2.28 \\
\hline El-Negala & $\Xi$ & 1.04 & 0.10 & 5.31 & 6.44 & 0.96 & 1.71 \\
\hline Sidi Braani & & 0.68 & 0.10 & 5.36 & 6.14 & 1.44 & 1.48 \\
\hline El-Saloum & & 0.59 & 0.15 & 4.97 & 5.71 & 0.43 & 1.88 \\
\hline El-Dabaa E & & 0.27 & 0.20 & 1.02 & 1.49 & 0.00 & 0.86 \\
\hline El-Dabaa W & & 0.68 & 0.10 & 0.45 & 1.22 & 0.00 & 1.71 \\
\hline Alam Elrom & $\underline{\Xi}$ & 0.81 & 0.18 & 0.45 & 1.43 & 0.00 & 4.62 \\
\hline Mrsa Matrouh & $\Xi$ & 1.04 & 0.15 & 0.68 & 1.87 & 0.00 & 0.97 \\
\hline El-Negala & $\Xi$ & 0.50 & 0.15 & 0.63 & 1.28 & 0.00 & 1.77 \\
\hline Sidi Braani & & 1.26 & 0.15 & 0.29 & 1.70 & 0.00 & 0.68 \\
\hline El-Saloum & & 0.59 & 0.10 & 0.13 & 0.82 & 0.00 & 0.51 \\
\hline
\end{tabular}

Nitrite is the intermediate state between oxidation of $\mathrm{NH}_{4}{ }^{+}$to $\mathrm{NO}_{3}{ }^{-}$in nitrification and the reduction of $\mathrm{NO}_{3}{ }^{-}$to either $\mathrm{N}_{2} \mathrm{O} / \mathrm{N}_{2}{ }^{-}$molecules or $\mathrm{NH}_{4}{ }^{+}$in denitrification (Grasshoff 1976). Nitrite showed low concentrations for water samples in the study region. The values fluctuated between 0.00 and $0.28 \mu \mathrm{M}$ determined at stations of Mrsa Matrouh and El-Saloum during winter, respectively, with annual average of $0.12 \mu \mathrm{M}$ (Fig. 3b). It was observed that the decrease of nitrite could be attributed to assimilation by plants in addition to the de-nitrification process.

Seasonal variation of nitrate content in water samples fluctuated between 0.01 and 5.36 $\mu \mathrm{M}$ determined at El-Saloum and Sidi Braani during spring and summer, respectively with an annual average of $1.75 \mu \mathrm{M}$. It was observed that the decrease of nitrate during spring (Fig. 3c) could be attributed to assimilation by plants in addition to the de-nitrification process (i.e. the reduction of nitrate to nitrite before releasing $\mathrm{N}_{2} \mathrm{O}$ or $\mathrm{N}_{2}$ molecules). The data of ammonia and nitrate concentrations (Table 3) showed that the concentrations of nitrate were generally higher in summer, while the opposite trend was recorded for ammonia and nitrite concentrations in winter. This distribution may be due to more oxic conditions in the winter than summer (Table 2). 
Based on the annual average, nitrite is a minor constituent if dissolved inorganic nitrogen DIN consists of about $4.99 \%$ and nitrite is characterized as the intermediate compound which could be derived either from the reduction of nitrate or oxidation of ammonia and during nitrogen assimilation can be removed from solution by phytoplankton (Schuler et al., 1953). Nitrate comprises the majority of DIN (Fig. 3d) and represents about 53.78\% whereas; ammonia comprises about $42.64 \%$ of DIN.

Phosphorus is very important element in the aquatic system for primary production. It is important for growth and reproduction of phytoplankton (Riley and Chester, 1971). The distributions of inorganic phosphate were presented graphically in Fig. (3e). The values of inorganic phosphate are depletion at most stations to 2.45 $\mu \mathrm{M}$ at El-Dabaa W. Concentrations of phosphate were always low at most locations of the present study and are principally related to its short residence time in seawater. The seasonal averages of phosphate concentrations were in the following order: winter $>$ summer $>$ spring $>$ autumn (ND).

(a)

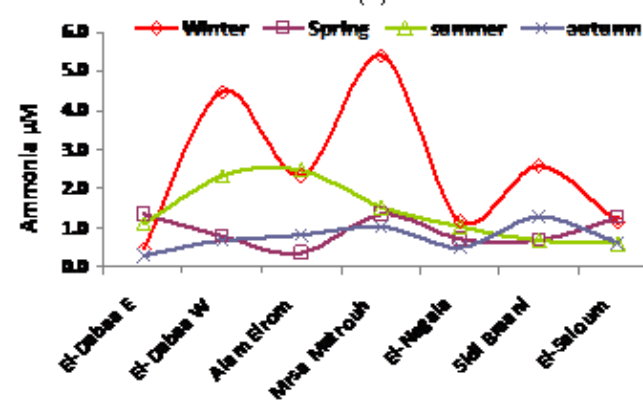

(c)

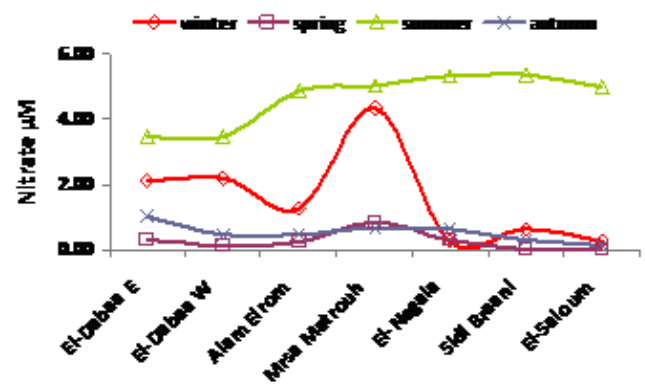

(e)

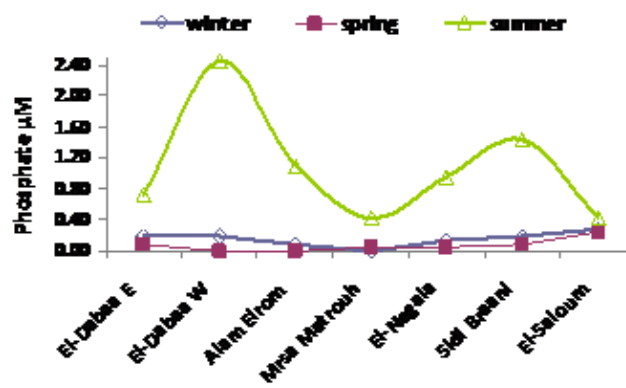

(b)

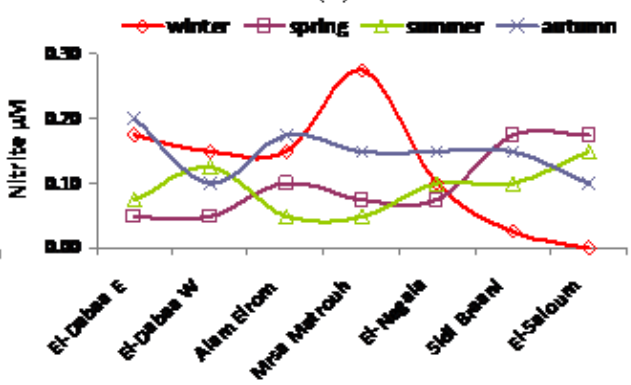

(d)

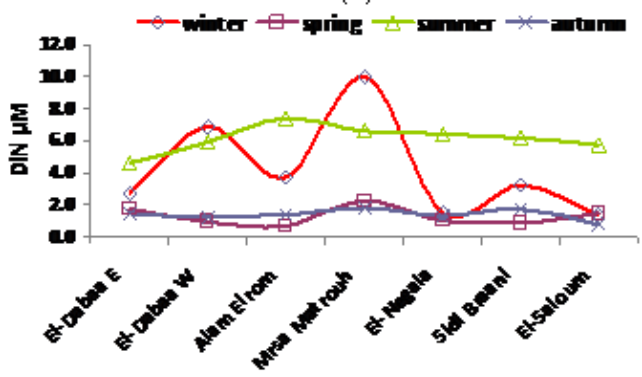

(f)

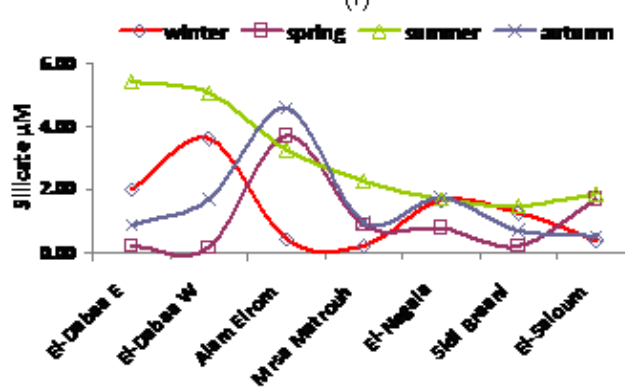

Fig. 3: Seasonal distribution of nutrients collected from El-Dabaa to El-Saloum along the Egyptian Mediterranean Sea during 2014.

Silicate is the major nutrient for diatoms, which are the dominant phytoplankton organisms in the sea (Riley and Chester 1971). The spatial distributions of silicate are presented graphically in Fig. (3f). The minimum absolute 
value $(0.17 \mu \mathrm{M})$ was recorded during spring at El-Dabaa $\mathrm{W}$, while the maximum one $(5.42 \mu \mathrm{M})$ was observed at El-Dabaa W during summer. The seasonal averages of silicate concentrations were in the following order: summer $>$ autumn $>$ winter $>$ spring.

Therefore, water quality of study area from El-Dabaa to El-Saloum is good; within the permissible limits in the majority of monitoring sites, and results indicated that all stations were generally between Oligotrophic and mesotrophic (low and medium level of nutrients) (Adapted from Vucak, Skrivanic \& Strin 1982). This region is not adversely affected by existing development and is accordance with annual report on water quality data from the coastal waters of the Mediterranean Sea.

\section{Amino acids in sediments}

The amino acid distributions for the seven stations of the investigated area during summer were reported in Fig. (4). Distribution and composition of amino acids showed variation from a minimum of $1884.5 \mu \mathrm{M}$ recorded at El-Dabaa $\mathrm{E}$ to a maximum of $19569.6 \mu \mathrm{M}$ at Sidi Braani with an average of $12484 \mu \mathrm{M}$. High concentrations were also detected at El-Dabaa W, Sidi Braani and El-Saloum, while Alam Elrom and Mrsa Matrouh were relatively depleted in amino acids.

Aliphatic amino acids (alanine, serine, glycine and isoleucine) were detected at very low levels $(0.06 \%-2.78 \%)$, while threonine was at wide range of concentrations (3.8\%-83\%); in contrast, leucine was not detected. Amino acids containing sulphur; cysteine was found at El-Saloum station with concentration of $3974.6 \mu \mathrm{M}(22 \%)$, but methionine was not detected. Mono-aminodicarboxylic acids and their amide glutamic and aspartic acids were detected at El-Saloum station (2.26\%); El-Negala and El-Saloum (1.45-13.4\%). Basic amino acids arginine and lycine were present at low concentrations not exceeding $1.93 \%$ at El-Dabaa W, Negala, El-Saloum stations.

Aromatic amino acids phenylalanine and tyrosine were present at considerable levels $4.6-56.2 \%$ and $0.3-72.5 \%$ respectively. This reflects that on an average scale, aromatic amino acids in sediments of the Egyptian coast are higher than the aliphatic by a factor of 3.4 and also strong predominance of aromatic tyrosine $(72.5 \%)$ and phenylalanine (56.2\%) at El-Dabaa W and El-Saloum stations respectively. Leucine, histidine and methionine were not detected in the sediments of this area.

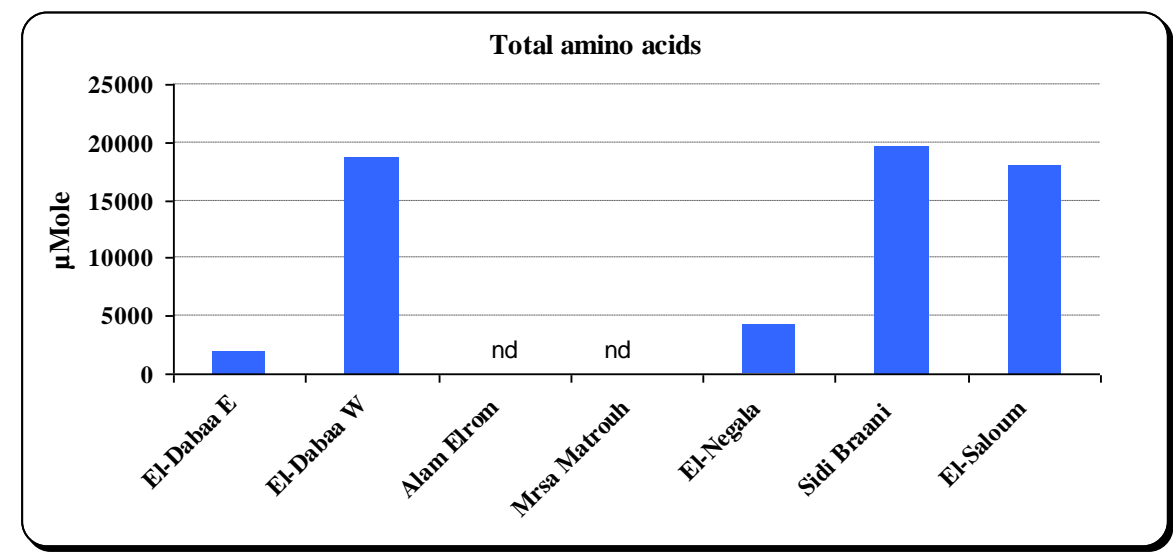

Fig. 4: Total amino acids in sediment collected from El-Saloum to El-Dabaa along the Egyptian Mediterranean Sea during summer 2014.

Linear regression equation between concentrations of amino acids and their molecular weight (MW) showed that amino acids increase with increasing their molecular weight (Fig. 5), according to the formula:

Amino acid concentrations $=-\mathbf{- 5 . 2 5} \mathrm{MW}+\mathbf{5 3 . 0 5} \mathrm{r}=\mathbf{0 . 5 0}, \mathrm{n}=32, \mathrm{P}\{0.01\}$ 
The effects of physico-chemical parameters of seawater: temperature (T), salinity (S), $\mathrm{pH}, \mathrm{DO}, \mathrm{NO}_{2}^{-}, \mathrm{NO}_{3}{ }^{-}, \mathrm{PO}_{4}{ }^{3-}, \mathrm{DIN}, \mathrm{TN}$ and $\mathrm{SiO}_{4}{ }^{2-}$ on the concentration of total amino acids showed that during summer 2014, these compounds increase by increasing temperature $(\mathrm{r}=0.69), \mathrm{pH}(\mathrm{r}=0.58)$, $\mathrm{DO}(\mathrm{r}=0.59)$, and $\mathrm{NO}_{2}^{-}(\mathrm{r}=0.706)$, while the effects of other environmental conditions were negligible. However, no significant correlation were found between amino acids and both TN and TOC in sediment.

The results of amino acids in the investigated area is comparable with total amino acids of the Eastern Harbor that is varied widely between $1021 \mu \mathrm{g} / \mathrm{g}$ in winter and $11843 \mu \mathrm{g} / \mathrm{g}$ in spring (Gouda et al., 2006).

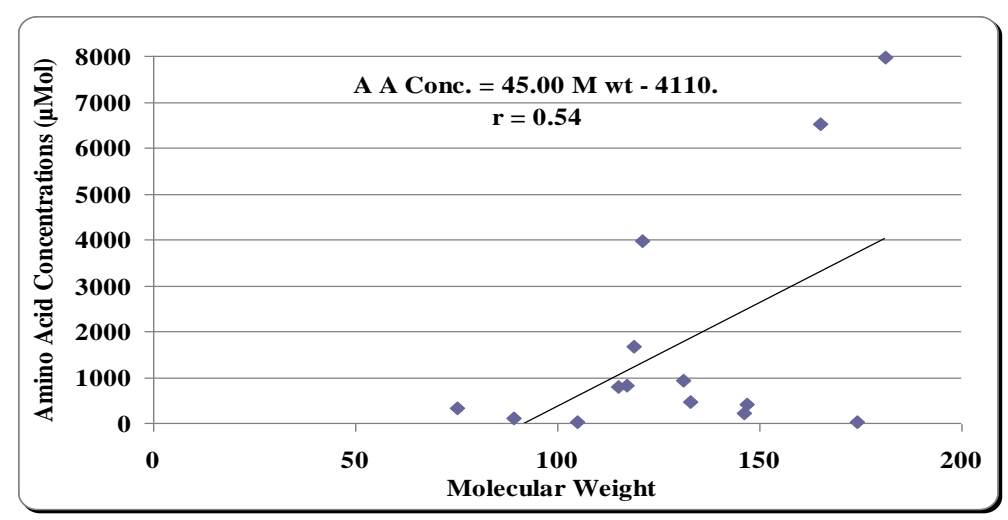

Fig. 5: Amino acids-Molecular weight relationship in sediments of study area during summer 2014.

\section{Petroleum Hydrocarbons}

\section{Aliphatic and aromatic hydrocarbons in water}

Aliphatic hydrocarbons concentrations in seawater were below the detection limit during winter and summer seasons; Excepting only $\mathrm{C}_{14}(10 \mathrm{ng} / \mathrm{l}), \mathrm{C}_{29}(31.2 \mathrm{ng} / \mathrm{l})$ were detected at El-Dabaa $\mathrm{E}$ and Mrsa Matrouh, respectively in winter, and $\mathrm{C}_{17}, \mathrm{C}_{18}$, $\mathrm{C}_{19}, \mathrm{C}_{23}, \mathrm{C}_{25}, \mathrm{C}_{26}$ (3-6 ng/l) at Sidi Braani in summer; revealing high values by 14.5 times during summer season than winter. For aromatic fraction, the concentrations were also below the detection limit except naph (39 ng/l) was detected at El-Dabaa E station in winter, Flu, Pyr, BaA, BaP (1.5-4 ng/l) were detected at Sidi Braani station in summer; revealing the same trend for aliphatic one.

\section{Aliphatic and Aromatic hydrocarbons in sediments}

Values of total petroleum hydrocarbons were presented graphically in Fig. (6). The highest concentrations (3086, 469.7ng/g), observed at El-Dabaa E and Alam Elrom during winter and summer season, respectively, with depletion in TPH concentrations at El-Dabaa W, El-Negala in winter, Sidi Braani in summer, respectively. The average value of petroleum hydrocarbons were in the following order: winter $>$ summer.

The concentrations of aliphatic fraction in sediments during winter season for El-Dabaa E station exhibited the following values, $\mathrm{C}_{14}(26 \mathrm{ng} / \mathrm{g}), \mathrm{C} 19(11 \mathrm{ng} / \mathrm{g}), \mathrm{C}_{21}$ $(24.7 \mathrm{ng} / \mathrm{g}), \mathrm{C}_{23}(6.7 \mathrm{ng} / \mathrm{g}), \mathrm{C}_{29}(32.5 \mathrm{ng} / \mathrm{g}), \mathrm{C}_{30}(135 \mathrm{ng} / \mathrm{g})$ and $\mathrm{C}_{31}(1034 \mathrm{ng} / \mathrm{g})$, representing a total concentrations of $1269.9 \mathrm{ng} / \mathrm{g}$ in winter. In addition, the concentrations determined at Alam Elroom, Mrsa Matrouh, Sidi Braani and ElSaloum being $478.1 \mathrm{ng} / \mathrm{g}$. Thus for the winter, total concentrations were found to be $1748 \mathrm{ng} / \mathrm{g}$ for the study area.

During summer, aliphatic hydrocarbons represent $153.4 \mathrm{ng} / \mathrm{g}$ for El-Dabaa W, Alam Elrom, Mrsa Matrouh, El-Negala and El-Saloum, reflecting higher 
concentrations in winter by 11.4 times than summer; showing the same trend for seawater. In addition, the highest concentrations were recorded for higher carbon number $\mathrm{C}_{29}, \mathrm{C}_{31}$ of both seawater and sediments. Similar results were reported by ElDeeb and Emara (2005) for aliphatic hydrocarbons of Mediterranean seawater west of Alexandria.

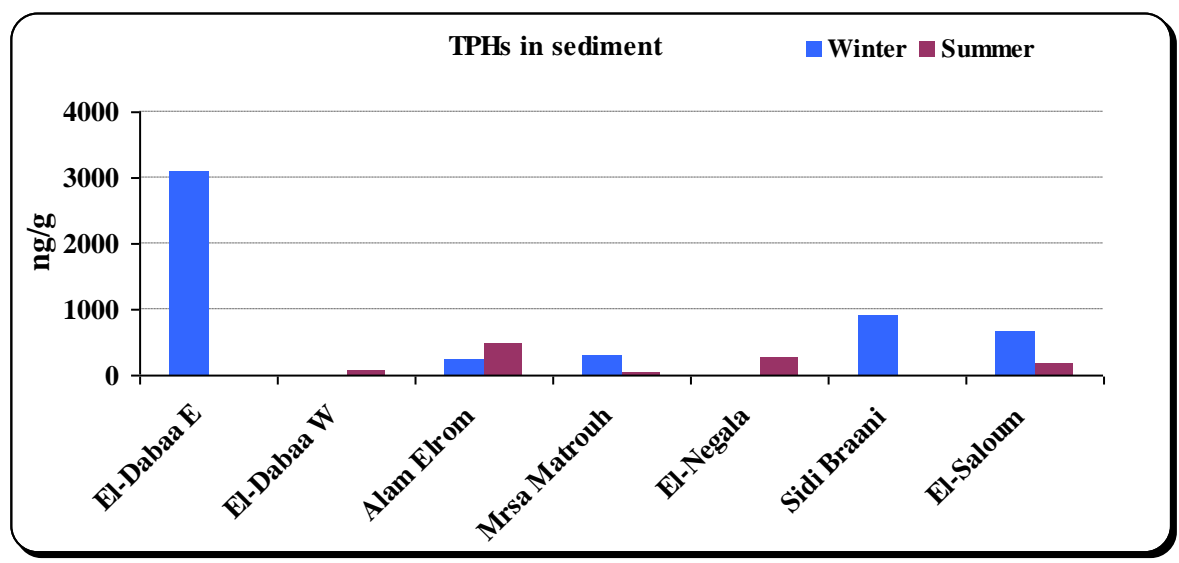

Fig. 6 Total petroleum hydrocarbons (ng/g) in sediment collected from El-Dabaa to El-Saloum along the Egyptian Mediterranean Sea.

Generally, the aromatic hydrocarbon concentrations of sediments ranged from $\mathrm{ND}$ to $3602.3 \mathrm{ng} / \mathrm{g}$ in winter with a decreasing order for the stations, El-Dabaa E > Sidi Braani > El-Saloum > Mrsa Matrouh > Alam Elrom, while in summer, the total concentration was found to be $856.1 \mathrm{ng} / \mathrm{g}$; showing the following trend stations: Alam Elrom > El-Negala > El-Saloum > El-Dabaa W > Mrsa Matrouh > El-Dabaa E, with a winter/summer ratio of 4.2 (Table 2). In addition; the concentrations of aromatic hydrocarbon compounds in a decreasing order were $\mathrm{BaA}>\mathrm{B}$ (ghi) $\mathrm{P}>\mathrm{InP}$ $>$ Acthy $>\mathrm{Chr}>$ Ace $>\mathrm{Pyr}>\mathrm{BbF}>\mathrm{Phe}>\mathrm{BaP}>\mathrm{BkF}>\mathrm{Flu}>\mathrm{AnT}$. For aromatic fractions in seawater the concentration was in the order Naph $>\mathrm{Pyr}>\mathrm{BaP}>\mathrm{BaA}>$ Flu. For aliphatic hydrocarbons, concentration factor of sediments/water during winter and summer being 5.4 and 6.9 respectively, while for aromatic fractions; the ratios were 11.2 and 10.3 nearly two times higher respectively.

On the concentration of TPHs showed that these compounds increase by decreasing $\mathrm{S} \%$ o $(\mathrm{r}=-0.78, \mathrm{P}<0.05), \mathrm{T}^{\circ} \mathrm{C}(\mathrm{r}=-0.53 \mathrm{P}<0.05)$ and TOC\% $(\mathrm{r}=-0.77$, $\mathrm{P}<0.05)$, according to the equations: TPHs concentrations $\mathrm{y}=-0.2937 \mathrm{~S} \%+$ $38.438, \mathrm{y}=-2.348 \mathrm{~T}+22.942, \mathrm{y}=0.0257 \mathrm{TOC}+0.1422$ (Fig. 7); while the effect of other environmental parameters are negligible. This is most probably attributed to the ability of petroleum hydrocarbons to be adsorbed onto bottom.
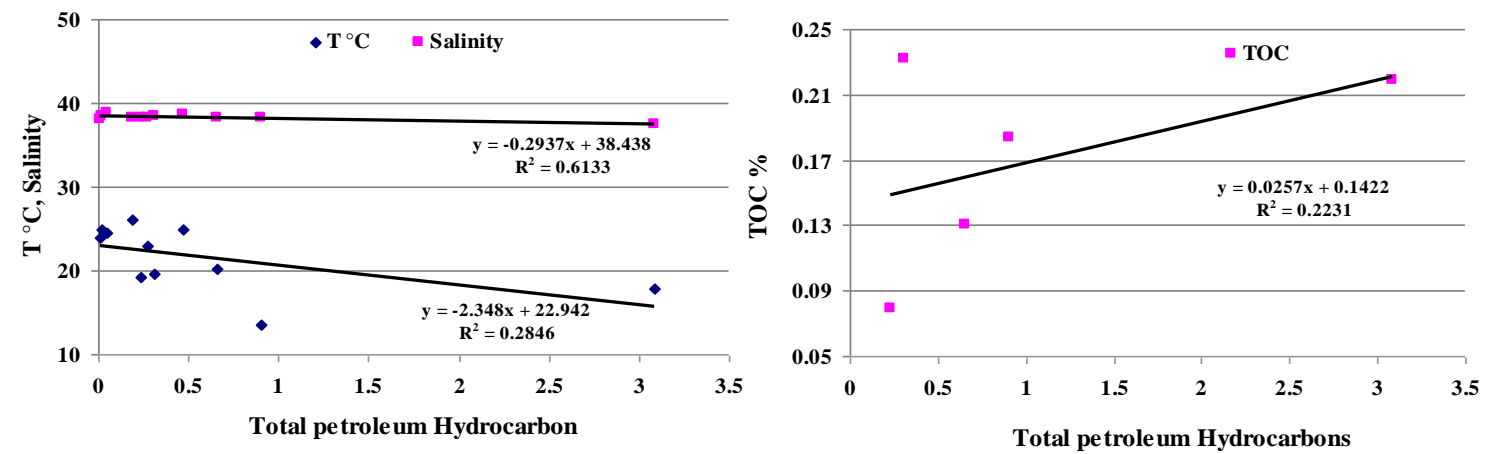

Fig. 7: Correlation between TPHs and each salinity, temperature and TOC\% in the area of study 


\section{OCPs and PCBs in the seawater and sediments}

There is complete depletion of OCPs and PCBs in the seawater samples of the study area during summer and winter seasons; except $\mathrm{B}-\mathrm{HCH}$ was detected with very low concentration $0.141 \mathrm{ng} / \mathrm{l}$ at El-Dabaa E. For sediment samples; the sum of total pesticides varied from below detection to $120 \mathrm{ng} / \mathrm{g}$ (Table 4). High value (120ng/g) was observed only at El-Saloum at summer season. The order of decreasing concentrations in sediment samples during winter season was: El-Dabaa W > ElDabaa E > Mrsa Matrouh with complete depletion of OCPs in the other stations. HCHs were below detection limits in the sediment and this may attributed to higher vapor pressure of these compounds which facilitate relatively rapid atmospheric dissipation in the tropics, leaving fewer residues in soil and water.

Table 4: Concentration of chlorinated pesticides, PCBs, TPHs (ng/g) measured in sediment samples collected from El-Dabaa E to El-Saloum of the Egyptian Mediterranean Coast.

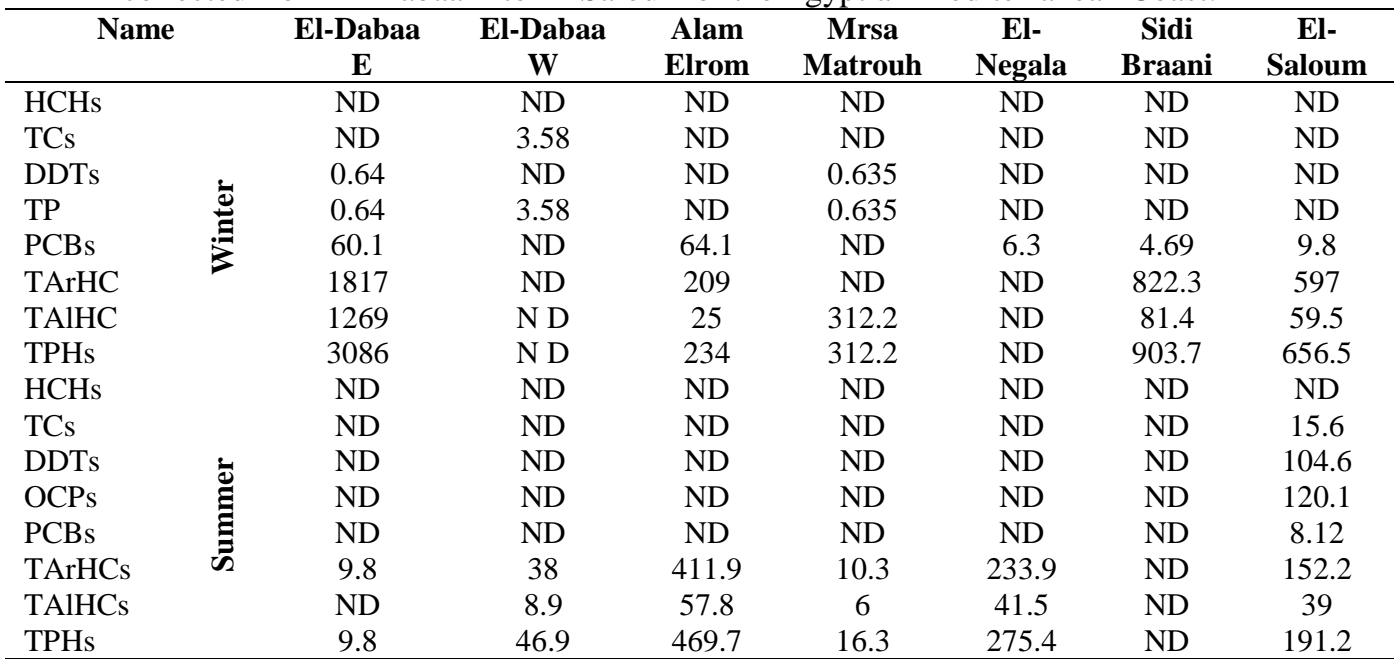

ND: below detection limit, $\mathrm{HCHs}=\alpha-\mathrm{HCH}+\beta-\mathrm{HCH}+\gamma-\mathrm{HCH}, \mathrm{TCs}=$ aldrin + dieldrin + endrin, DDTs=o, $\mathrm{p}^{\prime}-\mathrm{DDE}$ + p, $\mathrm{p}^{\prime}-\mathrm{DDE}+$ o, $\mathrm{p}^{\prime}-\mathrm{DDD}+\mathrm{p}, \mathrm{p}^{\prime}-\mathrm{DDD}+\mathrm{o}, \mathrm{p}^{\prime}-\mathrm{DDT}+\mathrm{p}, \mathrm{p}^{\prime}-\mathrm{DDT}, \mathrm{OCPs}=\Sigma \mathrm{HCHs}+\Sigma \mathrm{Cs}+\Sigma \mathrm{DDTs}, \Sigma \mathrm{PCBs}=\mathrm{PCB} 28$ + PCB 52 + PCB $101+$ PCB 118 + PCB 153 + PCB 138 + PCB 180, TArHCs= total aromatic hydrocarbons, $\mathrm{TAlHCs}=$ total aliphatic hydrocarbons.

Cyclodienes also not detected in the sediment, except at El-Dabaa W (3.58 $\mathrm{ng} / \mathrm{g})$ in the winter and at El-Saloum $(15.6 \mathrm{ng} / \mathrm{g})$ in the summer. The presence of Dieldrin values of $3.58,1.9 \mathrm{ng} / \mathrm{g}$ at El-Dabaa $\mathrm{W}$ and El-Saloum in winter and summer; respectively, and $13.7 \mathrm{ng} / \mathrm{g}$ of Endrin in summer; declared that Aldrin is converted into its epoxide form; Dieldrin and then rearrangement to endrin (GESAMP, 1993) in sediment of the study area.

DDTs compounds, in particular its metabolite p,p -DDT was only detected at El-Dabaa E and Mrsa Matrouh in winter with values of 0.64 and $0.635 \mathrm{ng} / \mathrm{g}$ respectively. Total concentration of DDTs was found to be $104.6 \mathrm{ng} / \mathrm{g}$ at El-Saloum in summer.

Concentrations of PCBs in winter showed the following congeners PCB 28 (6.3 ng/g, El-Negala), PCB52 (64.1 ng/g, Alam Elrom), PCB 101 (4.69 ng/g, Sidi Braani), (9.827ng/g, El-Saloum). While, in summer showed the following congeners PCB101 (3.8 ng/g, El-Saloum), PCB 153 (0.5ng/g, El-Saloum), PCB 138 (60.1 ng/g, El-Dabaa E). Total concentrations of PCBs in winter and summer were found to be $145 \mathrm{ng} / \mathrm{g}$ and $8.12 \mathrm{ng} / \mathrm{g}$ respectively; with ratio of 18.08 .

In marine sediments, the average concentrations of pesticides, PCBs, TPHs were much lower in sediment of the western part of the Egyptian Mediterranean 
coast compared to other study sites. These data are in agreement with the data recorded in Western Mediterranean Sea coastal sediments (Shreadah et al. 2016) and lower than data previously measured in the Western coast of Alexandria, Egypt (Said, 2007) and Mediterranean Sea sediments (Guitierrez et al. 2007). Generally, it was observed that seawater from most sites did not show any levels of pesticides, PCBs and TPHs. These levels, if any, may have been much lower than the detection limit for the compounds analyzed. The present study indicated that all measured concentrations of pesticides, PCBs and petroleum hydrocarbons in the Egyptian coast of Mediterranean Sea were much lower than those reported as permissible levels. The maximum permissible levels recommended by the National Academy of Sciences and National Academy of Engineering [NAS-NAE, 1972] for organochlorine pollutants are 1000-5000 ng/g for PCBs and $100 \mathrm{ng} / \mathrm{g}$ for cyclodienes. The recommended levels by Swedish Food Regulation are $5000 \mathrm{ng} / \mathrm{g}$ for DDTs, $2000 \mathrm{ng} / \mathrm{g}$ for PCBs (SFR, 1983).

\section{CONCLUSION}

This study represent an important data regarding environmental parameters as well as amino acids, petroleum hydrocarbons, pesticides and PCBs in water and sediment of the western section of the Egyptian Mediterranean Sea from El-Dabaa to El-Saloum during the year 2014. The measurements of physico-chemical parameters and nutrients in water collected from the study area indicated that water quality from El-Dabaa to El-Saloum is good; within the permissible limits in the majority of monitoring sites, and all stations were generally between oligotrophic and mesotrophic (low and medium level of nutrients), and this area is not adversely affected by existing development. Furthermore, Seawater from most sites did not show any levels of pesticides, PCBs and TPHs. These levels, if any, may have been much lower than the detection limit for the compounds analyzed. In marine sediments, the average concentrations of amino acids is similar to other comparable areas, while pesticides, PCBs, TPHs were much lower in sediment of the western part of the Egyptian Mediterranean coast compared to other study sites.

\section{ACKNOWLEDGMENTS}

The authors would like to express their sincere gratitude to NIOF (National Institute of Oceanography and Fisheries) for financial support to accomplish this work.

\section{REFERENCES}

Barakat, A. O.; Kim, M.; Qian, Y.; Wade, T. L. (2002). Organochlorine pesticides and PCB residues in sediments of Alexandria Harbour, Egypt. Mar. Pollut. Bull., 44: 1421-1434.

Carlberg, S. R. (1972). New Baltic Manual. Int. Coun. for the exploration of the sea. Cooperative Res. Rep. Series, No. 29 Copenhagen.

De Voogt, P. and Brinkman, U. A. T. (1989). Production, properties and usage of polychlorinated biphenyls. In: Jensen, K. (Ed.), Canadian Council of Ministers of the Environment. Elsevier Science Publishers, Amsterdam, the Netherlands, pp 3-43. 
El-Deeb, Z. K.; Said, O. T.; El-Naggar, H. M. and Shreadah A. M. (2007). Distribution and Sources of Aliphatic and Polycyclic Aromatic Hydrocarbons in Surface Sediments, Fish and Bivalves of Abu Qir Bay, Bulletin Environmental Contamination Toxicology 78 (5): 373 - 379.

El-Deeb, Z. K.. and Emara, I. H. (2005). Polycychic aromatic hydrocarbons and Aromatic plasticiser materials in seawater of Alexandria coastal area. Egyptian Journal of Aquatic Research, 31: 15-24.

El-Naggar, A. N.; Emara, I. H; Rifaat, E. A.; Said, O. T.; Abou-Shahba, M. R.; Shaltout, A. N. and El-Naggar, F. M. (2013). Some Anthropogenic Driven Toxic Pollutants in El-Max Bay and its Neighborhood, Alexandria, Egypt", World Applied Sciences Journal, 21(10): 1512-1520.

Emara, I. H.; Shreadah, A. M.; Maoustafa, H. T. and El-Deek, S. M. (1992). Effects of Sewage and Industrial Wastes on the Chemical Characterstics of the Eastern harbor and El- Max Bay Waters of Alexandria, Egypt, Science of the Total Environment, pp. 773-784.

Emara, H. I. (1983). Dissolved amino acids in the coastal water of Alexandria, Rapp. Comm. Int. Mer. Medit, 28 (7): 73-76.

Emara, I. H; Abou-Shahba, M. R.; Said, O. T.; Attia, M. E. and El-Naggar, A. N. (2010). Chlorinated pesticides and polychlorinated biphenyls in sea water from semi-enclosed basin of the Mediterranean Sea Alexandria, INOC-Tischreen University, International conference on Biodiversity of the Aquatic Environment, Lattakia-Syria, 13-15 December, pp. 419-428.

FAO (1976). Manual of Methods in Aquatic Environmental Research Part I: Permanganate value (oxidiability) of organic matter in natural waters. FAO Fisheries Technical paper, 137: 169.

Fathy, S. A. H.; Abdel Hamid F. A.; Shreadah, M.A.; Mohamed, L. A. and El-Gazar, M. (2012). Application of Principal Component Analysis for Developing Water Quality Index for Selected Coastal Areas of Alexandria Egypt, Recourses and Environment Journal, 2 (6): 297-305.

GESAMP (1993). Impact of oil and related chemicals and wastes on the marine environment, Report Studies, 50: 1-180.

Gouda, M. K.; Jammo, K. M. and Awad, H. E. (2006). Distribution of heterotrophic amino acids aerobic marine bacteria in sediments, in Eastern Harbor of Alexandria. Annals of Microbiology, 56 (4): 259-304.

Grasshoff, K. (1976). Methods of sea water Analysis, Verlag Chemie Weinhein, New York, 1-317.

Guitierrez, A. G.; Garnacho, E.; Bayona, J. M. and Al-baiges, J. (2007), Screening Ecological Risk Assessment of Persistent Organic Pollutants in Mediterranean Sea Sediments, Environment International, 33(7): 867-876.

Hutzinger, O.; Safe, S. and Zitko, V. (1974). The Chemistry of PCBs, CRC Press, Boca Raton, FL.

Iwata, H.; Tanabe, S.; Sakai, N. and Tatsukawa, R. (1993). Distribution of persistent organochlorines in the oceanic air and surface seawater and the role of ocean on their global transport and fate, Environ. Sci. Technol., 27: 1080-1098.

Jiang, Y.; Wang, X.; Jia, Y.; Wang, F.; Wu, M.; Sheng, G. and Fu, J. (2009). Occurrence, distribution and possible sources of organochlorine pesticides in agricultural soil of Shanghai, China, J. Hazard. Mater, 170: 989-997.

Koziol, S. A. and Pudykiewicz, A. J. (2001). Global-scale environmental transport of persistent organic pollutants. Chemosphere, 45: 1181-1200. 
Lundgren, K.; Tysklind, M.; Ishaq, R.; Broman, D. and Van Bavel, B. (2002). Polychlorinated naphthalene levels, distribution, and biomagnification in a benthic food chain in the Baltic Sea. Environ. Sci. Technol, 36: 5005-5013.

Müller, P. J., Suess, E. and Ungerer, A. C. (1986). Amino acids and amino sugars of surface particulate and sediment trap material from waters of the Scotia Sea, Deep-Sea Res., 33: 819-838.

National Academy of Sciences and National Academy of Engineering, Ecol Research Services Environmental, NAS-NAE, Washington, DC, 1972.

Riley, J. P. and Chester, R. (1971). Introduction to Marine Chemistry, Acad. Press., London and New York, p. 465.

Riley, J. P.; Grasshoff, K. and Voipio, A. (1978). Nutrient chemicals in a guide to marine pollution. Ed. Golberg, E.D. and Breach Science Publ. New York, p. 81

Said, O. T. (2007). Determination of Persistent Organic Pollutants in Sediment and Fish of the Western Coast of Alexandria, Egypt". Chemistry and Ecology 23(4): 289-302.

Schuler, J. F.; Diller, V. M. and Kersten, H. J. (1953). Preferential assimilation of ammonium ion by Chlorella vulgaris. Plant Physiol, 28: 299-303.

SFR, Foreign Substances in Food. The National Food Administration SLVFS: 1, Swedish Food Regulation, Uppsala, 1983.

Shreadah, A. M.; Said, O. T; Mansour, A. M.; El-Sharkawi M. F. and Mohamed A. M. (2016). POPs in Sediments from the Eastern and Western Egyptian Mediterranean Coast; a Comparative Study, Development in Analytical Chemistry (DAC), Vol. 3 .

Shreadah, M. A.; Said T. O.; Othman, I. M., Fathallah, E. M. I. and Mahmoud, M. E. (2014). "Organochlorines in Seawater from Egyptian Mediterranean Coast of Alexandria". Development in Analytical Chemistry, 1: 19-24.

Tada, K.; Tada, M. and Maita, Y. (1998). Dissolved Free Amino Acids in Coastal Seawater Using a Modified Fluorometric Method, Journal of Oceanography, 54: 313-321.

Tadros, A. B.; Hamaida, H. A. E. and Said, T. O. (2005). Chemical characteristics of El-Mex fish farm ponds. Egypt. J. Aquatic. Research, 31 (special issue), 191212.

UNEP/IOC/IAEA (1991). Sampling of selected marine Organisms and sample preparation for the analysis of chlorinated hydrocarbons. Reference methods for marine pollution studies no. 12, revision 2. Nairobi: United Nations Environment Programme, 17.

UNEP/IOC/IAEA (1992). Determination of petroleum hydrocarbons in sediments, Reference Methods for Marine Pollution Studies, 20, UNEP, p. 75.

UNESCO/WHO (1978). Water quality survey, Studies and reports in hydrology, No. 23. Paris: United Nation Educational Scientific and Cultural Organization and World Health Organization.

Valderama, J. C. (1981). The simultaneous analysis of total nitrogen and total phosphorus in natural water, Marine Chemistry, 10: 109-122.

Volkman, J. K.; Holdsworth, D. G.; Neil, G. P. and Bavor Jr, H. J. (1992). Identification of natural, anthropogenic and petroleum hydrocarbons in aquatic sediments. Science of the Total Environmental, 112: 203-219.

Vucak, Skrivanic and Strin, J. (1982). Basic physical chemical and biological data reports, R.V.A 
Wakeham, S. G.; Lee, C.; Hedges, J. I.; Hernes, P. J. and Peterson, M.L. (1997). Molecular indicators of diagenetic status in marine organic matter, Geochim. Cosmochim. Ac., 61: 5363-5369. 